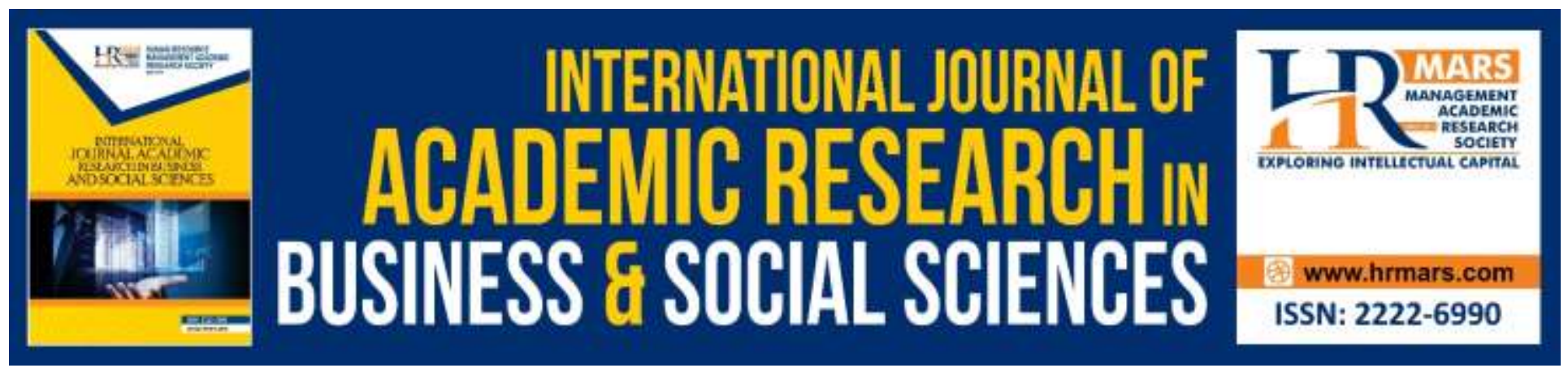

\title{
Terrorism and its Implications on Small Hotels in Sri Lanka
}

Sathiamoorthy V., De Zilva M. M. S., Bandara E. C. P. K., Leelarathne E. K. C. J. S., Weligodapola H. W. M. C., Lokeshwara. A. A.

To Link this Article: http://dx.doi.org/10.6007/IJARBSS/v10-i5/7217

DOI:10.6007/IJARBSS/v10-i5/7217

Received: 14 March 2020, Revised: 18 April 2020, Accepted: 29 April 2020

Published Online: 19 May 2020

In-Text Citation: (Sathiamoorthy. et al., 2020)

To Cite this Article: Sathiamoorthy, V., Zilva, De. M. M. S., Bandara, E. C. P. K., Leelarathne, E. K. C. J. S., Weligodapola, H. W. M. C., \& Lokeshwara, A. A. (2020). Terrorism and its Implications on Small Hotels in Sri Lanka. International Journal of Academic Research in Business and Social Sciences, 10(5), 471-478.

\section{Copyright: (c) 2020 The Author(s)}

Published by Human Resource Management Academic Research Society (www.hrmars.com)

This article is published under the Creative Commons Attribution (CC BY 4.0) license. Anyone may reproduce, distribute, translate and create derivative works of this article (for both commercial and non-commercial purposes), subject to full attribution to the original publication and authors. The full terms of this license may be seen

at: http://creativecommons.org/licences/by/4.0/legalcode

Vol. 10, No. 5, 2020, Pg. 471 - 478

http://hrmars.com/index.php/pages/detail/IJARBSS

JOURNAL HOMEPAGE

Full Terms \& Conditions of access and use can be found at http://hrmars.com/index.php/pages/detail/publication-ethics 


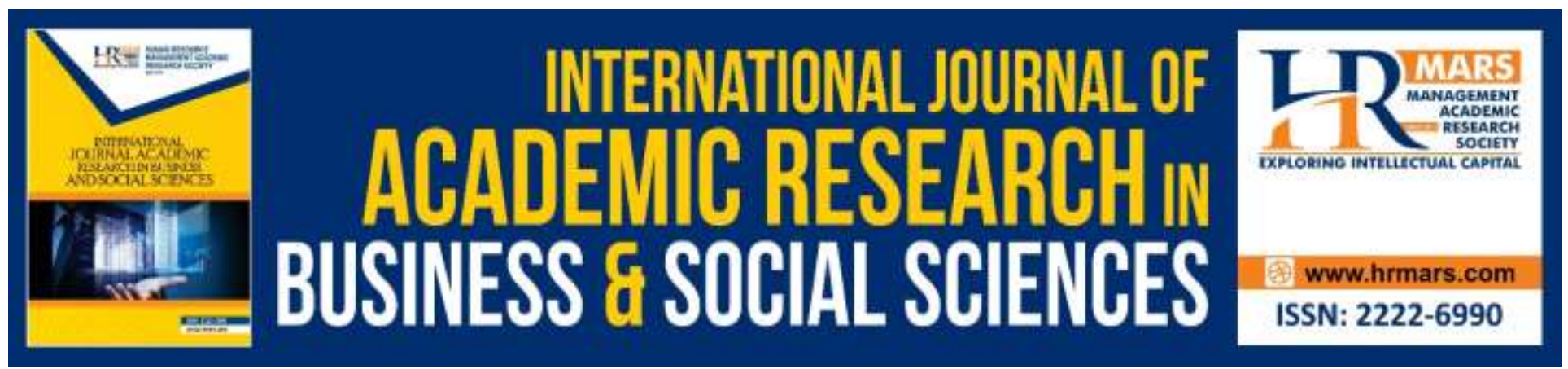

\title{
Terrorism and its Implications on Small Hotels in Sri Lanka
}

\author{
Sathiamoorthy V. ${ }^{1}$, De Zilva M.M.S. ${ }^{2}$, Bandara E.C.P.K. ${ }^{3}$, \\ Leelarathne E.K.C.J.S. ${ }^{4}$, Weligodapola H.W.M.C. ${ }^{5}$, \\ Lokeshwara.A.A. ${ }^{6}$
}

${ }^{1}$ Undergraduate, SLIIT, Business school, SLIIT, Malabe, Sri Lanka, ${ }^{2}$ Undergraduate, SLIIT, Business school, SLIIT, Malabe, Sri Lanka, ${ }^{3}$ Undergraduate, SLIIT, Business school, SLIIT, Malabe, Sri Lanka, ${ }^{4}$ Undergraduate, SLIIT, Business school, SLIIT, Malabe, Sri Lanka, ${ }^{5}$ Senior Lecturer, SLIIT, Business school, SLIIT, Malabe, Sri Lanka , ${ }^{6}$ Assistant Lecturer, SLIIT, Business school, SLIIT, Malabe, Sri Lanka.

Email: vinosathya07@gmail.com¹․milakshidezilva96@gmail.com²,pamukavi96@gmail.com³, jananisahana00@gmail.com ${ }^{4}$, mano.w@sliit.lk ${ }^{5}$, anuja.l@sliit.lk ${ }^{6}$

\section{Abstract}

The purpose of this study is to analyze whether there is an impact on small hotels throughout the island as a result of the Easter attack incident. It was noted that due to the Easter attack incident there was a decline in the number of tourist arrivals in Sri Lanka and this study attempts to identify the impact it posed on the small hotels in the country. The study has a sample of ten small hotels in Hikkaduwa area chosen through the snowball sampling method and deploys a pattern matching in analyzing data collected through face to face interviews. It was revealed in the study that there is an impact on the financial performance of the small hotels in Sri Lanka due to the Easter attack incident. The value of this study is to assist the small hotels in the analysis of direct and indirect effects of terrorism on their performance.

Keywords: Financial impact, Small hotels, Sri Lanka, Terrorism, Tourism.

\section{Introduction}

Terrorism is the unlawful use of power or violence against entities or property to harass or force a government or its people to chase certain political or societal goals (Jenkins, 2020). According to Saint-Pierre (2003) terrorism can be stated as a "political violence in which they have no ability to surmount their opponents. Terrorism's aim is to allow them more damage than they themselves can tolerate". In more local context, terrorism has been evident in Sri Lanka for a considerable period, extremely damaging events occurred during the stages of the Sri Lankan civil war (1983- 2009). The Liberation Tigers of Tamil Elam (LTTE) was mainly accused with causing vast demolition in the nation, and the impact was seen in social, political and economic aspects. Operations of the LTTEs' led to the Sri Lankan civil war which lasted three decades. After the civil war, the most recent terror attack 
witnessed by Sri Lanka was the Easter Sunday Attack which took place on 21 ${ }^{\text {st }}$ April, 2019 (Aljazeera, 2019). The objective of this study is to identify how Easter Sunday attacks has impacted the small hotels in Sri Lanka.

Tourism has been recognized in both developed and developing countries as a major financial and social contributor. And according to one of the recent publications of Lonely Planet 2019 Sri Lanka is one of the best tourist destinations in the world and it is a country with unique scenic beauty (The Guardian, 2019). The land is trailed with countless natural sights, including a combination of rivers, steamy valleys, gusty mountains and waterfalls, providing a wonderful atmosphere. As a tourist attraction point, Sri Lanka has capacity to develop further in terms of tourism. The government and the Sri Lanka Tourism Development Authority is now reforming the strategies to enhance the tourism sector, since it was identified as a lucrative sector that will yield positive outcomes to the national economy of Sri Lanka (Sri Lanka Tourism Development Authority, 2019).

However due to the suicide assaults that took place in churches and hotels in Sri Lanka on the $21^{\text {st }}$ of April 2019, which was an Easter Sunday, referred to as the Easter Attacks. Over 320 persons were reported dead in Sri Lanka from the Easter Attacks, and among the deceased were 40 tourists (Ethirajan, 2019). Due to terrorists targeting the hotels tourists are becoming fearful and are hesitant to visit Sri Lanka. It has a huge impact on the small hotels in tourism industry because the retention of tourists is the fundamental factor that generates revenue to the small hotels as well as the country.

Due to the Easter attacks the expenses of the small hotels rose by a certain level due to improvements in security measures and high promotions given to both local and foreign tourists, in an attempt to at least reach the breakeven. This study attempts to identify the impact of terrorism on financial performance of small hotels in Sri Lanka. This paper attempts to identify how terrorism could directly or indirectly affect the financial performance of small hotels in Sri Lanka which may be able to absorb and adapt to this form of volatility within a short period of time even though the impact decelerates the growth of the country.

\section{Research Objective}

This study is motivated by the fact that despite prior studies done regarding terrorism and tourism in Sri Lanka, no analysis had been done to observe the impact of terrorism on small hotels. The revenue of these hotels is based on the number of tourists who may be local or foreign. Small hotels in the tourism industry were affected by these terror attacks. Tourists select small hotels depending on their comfort and affordability, which are two of the main factors that contribute to the revenue streams of these small hotels. The Easter attack might have inversely affected the financial performance of these small hotels due to the reduction in tourist arrivals. Since these hotels might not have adapted any proper tourist retention process, they are at risk of losing the small portion of tourists who may visit them, and due to unexpected events like the Easter attacks, most small hotels have been affected adversely. This research study has developed the objective considering the above mentioned situations as follows,

- To study the impact of terrorism on small hotels in Sri Lanka

\section{Problem Statement}

The Easter Sunday attacks have greatly changed the tourism and hospitality industry which is one of the most effective industries in Sri Lanka. At the time of this unfortunate event, there were 
INTERNATIONAL JOURNAL OF ACADEMIC RESEARCH IN BUSINESS AND SOCIAL SCIENCES Vol. 10, No. 5, May, 2020, E-ISSN: 2222-6990 @ 2020 HRMARS

many foreign nationals in Sri Lanka, who fell victim to this chain of attacks that took place targeting churches and hotels. Some were killed while some were severely injured.

This outrageous terrorist act tarnished the image and attraction that Sri Lanka had developed since 2009, which marked the end of a three decade long civil war. Small hotels that have been affected by terrorism are a prominent part of the tourism industry and due to the Easter Sunday attacks, the reputation of Sri Lanka has been damaged intercontinentally.

Gupta (2011) conducted a study about terrorist attacks that had affected the financial performances of the tourism sector of India, in which he suggested that fear and concerns for safety were factors that reduced the number of tourist arrivals to the country. This can be further verified by Arana \& Leon (2008) who explained that there would be a drop in the number of tourist arrivals after a terrorist act because the tourists want to ensure their safety. Terrorism affects not only the properties and human life but also the sentiments of the stakeholders (Memdani \& Shenoy, 2019).

The United States of America (USA) and the United Kingdom (UK) were among the countries that issued red notices to their passengers regarding Sri Lanka (Ethirajan, 2019), and due to these red notices tourists refrained from visiting Sri Lanka. Statistics revealed a reduction of $70.8 \%$ of in the number of tourist arrivals in 2019 compared to the previous year as well as a $20 \%$ drop in the amount of check-ins at hotels (Mariathasan, 2019). On account of this drastic reduction in tourist arrivals, the reduction in sales has led many small hotels in Sri Lanka to close down their branches around the country, lay off employees or even close down completely.

\section{Literature Review}

There are many studies that have been done based on terrorism and its impacts on tourism. The International Labor Office in Geneva conducted a report on the social effects on the hotel and tourism industry after the September 11 incident in late 2001. According to Henderson et al. (2010), different people perceive terrorism differently. Korstanje \& Clayton (2012) discuss that citizens may come against the government if they feel the government cannot protect them. A few articles were done on whether there was a significant influence on the demand for tourism due to uncertainties which arose as a result of terrorism. These articles conclude that the number of tourist arrivals vary with the frequency of uncertainties, indicating that stronger the terrorist attack, greater the reduction in tourist arrivals ( Pizam \& Fleischer, 2002).

Pizam et al. (2000) explain that foreigners travel for business or leisure purposes with some image and knowledge in the form of previous memories in a country. Through various marketing strategies tourists are further attracted to the tourism sector in a particular nation and that creates images in the minds of the tourists which influence their perceptions. Gupta (2011) explains that tourism creates an extensive economic benefit to both the host country and the tourists' native country. In addition, this study reviews that tourism is a very important sector for developing economies. Baker (2014) argued that frustration of individuals in societies creates the terrorist activities and he further shows that tourists should be very careful in spending their holidays safely in any destination. Moreover, several studies found that natural disasters may also affect tourism up to a certain point, but terrorism affects the current and prospective tourists severely.

Henderson et al. (2010) argue that the reason, terrorists attack hotels because of quick and easy access at any time of the day, frequented mostly by foreigners and even other people gather together for meetings, hold conferences and have huge spaces where people cannot be easily identified. Kosová \& Enz (2012) found that terrorist attacks bring unpredictability and crisis situations 
later affected prices, revenue for available room as well as the residence of the accommodation business in the USA. Gupta (2011) described free flow of information, communication, information technology and so forth has posed an open challenge to the tourism industry since the terrorist groups are conducting their activities by seeking benefits from these technological developments, and hence affecting the countries globally. Kosová \& Enz (2012) stated that there would always be fluctuations in the performance indicators because of the uncertainties and may have an impact on different hotel segments. According to Kosová and Enz (2012), to identify the hotel performance through the environmental uncertainty, studying the factors such as size and monthly seasonality of hotels are insufficient, characteristics of the management are also useful. The purpose of this paper is to attempt to investigate terrorism and its implication on small hotels in Sri Lanka.

\section{Methodology}

In this research, the purpose is to study the impact of terrorist attacks on the financial performance of small hotels in Sri Lanka where the research has taken a qualitative approach in studying the impact of Easter attack incident on the small hotels. Data was collected through faceto-face interviews and questionnaires, with the hoteliers. The population of this research is small hotels all over the island. Interviews were piloted in the Hikkaduwa area since it is a destination where most tourists visit in Sri Lanka, according to the Tourism Board in Sri Lanka (Sri Lanka Tourism Development Authority, 2019). The research applied Snowball Sampling method to collect data and analyze the objective of this study. Ten hotels were selected as the sample and as snowball sampling method was deployed the participants were chosen by other participants. The data was collected to understand the impact of terrorism on small hotels in Sri Lanka. Hoteliers were given questionnaires to acquire the deep facts as well as to ensure the trustworthiness of the data. These are the main areas that the questionnaires were developed for:

- Understand the impact after the Easter Attack

- Understand the nature of the impact

- Financial impact to small hotels after the Easter Attack

This study used primary data that was qualitative in nature. The research aim was to do an analysis to define the level of impact of terrorism on small hotels in tourism industry in Sri Lanka. The objective was to study the impact of terrorism on small hotels in Sri Lanka from the data that was recorded. In the first step the data was transcribed and translated. The pattern matching helped to identify the patterns within all ten small hotels which were utilized for the purpose of this study.

\section{Findings}

Through the interviews, initially it was noted that most of the tourists preferred to spend the New Year's Eve in Sri Lanka. In spite of having all the favorable conditions and fondness, the Easter attacks have made a vast influence to the small hotels of tourism industry in Sri Lanka. Since the study was directed to ascertain the impact of Easter attacks on the financial performance of small hotels, the respondents of the interviews were the owners of the small hotels. The study selected ten establishments through snowball sampling method and all ten have agreed that there was an impact. Poseidon Diving Station, Coral Rocks, J L H Beach Restaurant, Hikka Regent Hotel, Refresh Beach Hotel, Farm House Restaurant and Bar Hikkaduwa, Coral Sands Hotel Hikkaduwa, Villa Red Lobster Hotel Hikkaduwa, Villa Paradise Hotel and Aroma Restaurant Hikkaduwa were the ten hotels in the sample of this study. 
This study emphasized the nature of the financial impact. Each hotel owner admitted that hoteliers were affected both financially and non-financially. In-depth interviews were conducted in order to find out answers for the following three aspects: the impact of the Easter attacks, the nature of the impact and financial impact to small hotels after the Easter attacks.

The researchers understood that the impacts ware quite drastic in all ten small hotels. The managers stated that, a major problem was the drastic reduction in the number of tourist visits which negatively impacted the small hotels. The interviewees mentioned that the number of bookings through the internet reduced and most of the bookings were either cancelled or postponed. Due to this, the revenue of the hotels was greatly impacted, hotel owners further emphasized that hoteliers were facing losses from daily operations and costs have been increasing with no income to outweigh them. Out of these ten small hotels all small hotels mentioned room occupancy of their hotels were reduced because of Easter attack incident. One of the hotel managers further stated,

"Before this incident, our guest arrivals were more than $80 \%$. But after this attack our guest arrivals decreased from $85 \%$ to $15 \%$. And also our profits have reduced from about Rs. 10,000,000 to Rs. 200,000 approximately. Because of that we couldn't cover up our main costs and cannot pay our loans"

\section{- Refresh Beach Hotel Manager}

Hoteliers said that normally the tourist season starts in November, and that even after eight months from the attacks no guests had arrived yet. Hence there were no sales and the survival of these eight months were done by drastically reducing the rates. Farm House Restaurant and Bar Hikkaduwa mentioned that there were no guest arrivals. The hotelier said,

"The economy is not at all successful even though the guest number was slightly increased in November. Normally we earn a huge profit from November to March. But now there were no profit because of Easter attacks incident. After the Easter attacks flight rates have been decreased due to the prevailing conditions. And, the tourism industry is facing a major drawback because of this incident. Sri Lanka is the best travel destination in the world. After the incident, Sri Lanka is not even included in the top ten countries to travel. Because Easter attacks hugely impacted the tourism sector, there was a lack of bookings and reduced number of guest arrivals in small hotels and restaurants. It was an enormous problem to tourism industry."

\section{- Farm House Restaurant manager}

The hoteliers further mentioned that they were unable to settle the bank loans. Identifying a break-even point helps to provide a dynamic view of the interactions between sales, costs, and profits and can also help hotels see where they could re-structure or cut costs for optimum results.

Another problem was paying employee salaries as there was no income due to the Easter attacks. Some of the hoteliers self-confessed that they could not pay workers those who worked in small hotels and restaurants and some workers have worked for minimal pay. Further, some had to take extreme measures to lay off the workers from the hotels. Three of the ten small hotels stated that they have had to lay off their employees because they do not have enough income to pay them. Hikka Regent Hotel manager described the drastic measures they had to take in order to maintain the breakeven within the company. In his words,

"Our income was reduced from $80 \%$ to $12 \%$ roughly. Then we could not pay our workers and we decided to fire five workers after the incident. Now we have only two workers. We understand that it is unfair for them but we had to make that decision. I cannot let my company run into losses...". 
INTERNATIONAL JOURNAL OF ACADEMIC RESEARCH IN BUSINESS AND SOCIAL SCIENCES Vol. 10, No. 5, May, 2020, E-ISSN: 2222-6990 ㄷ 2020 HRMARS

Poseidon Diving Station trainer further stated,

"I lost my contract after the Easter Sunday bomb attack. There were unexpected cancellations and eight of us lost our jobs in our hotel. I am trying to make a living by

offering some diving classes. But as you can see there are no more tourists compared to the previous seasons."

Researchers observed that in some small hotels, that some segments or parts were closed because if they were to open the hotel owners would have to bear the maintenance or operation costs, which they cannot afford. They cannot even cover up their variable costs since no guests have arrived after the Easter Attacks incident. Poseidon Diving Station trainer further stated,

"Before this incident we normally sent twenty boats for diving. In this season, today we only sent one boat for diving".

According to the above facts, the foremost impact was on the financial aspects of the tourism industry. Apart from which social, economic and legal aspects were also impacted by this unanticipated event.

\section{Conclusions}

Tourism is an important sector for the economy and its sustainability is important for the Sri Lankan economy. For decades tourism industry was one of the most revenue generating sectors of the country. However, terrorism has become a threat to the tourism industry and that is why it was required to do this study, in order to show how the Easter attack incident impacted small hotels in the tourism industry. According to the researchers' knowledge, small hotels were mostly affected by this incident and that encouraged the researchers to conduct this study on the impact of terrorism on small hotels in Sri Lanka. From the findings of the study it is possible to draw conclusions that terrorism has had a huge impact on small hotels. Through all the interviewed small hotels it was identified that there was an impact on the financial performance variables such as sales costs as well as tourist arrivals due to the Easter attack incident. The tourism sector should be protected with the involvement of the government and the national security of the nation should be amplified to combat against terrorism. This research was carried out in the Hikkaduwa region, located in the Southern province, however it is suggested to be extended to other areas of Sri Lanka where the arrivals of visitors are also strong and that is one recommendation for future studies. It is also recommended to identify other sectors, such as airlines, and insurance sector that may also be affected by terrorism. This study could also be extended beyond the areas such as legal effects as well as social, environmental, economic and cultural impacts.

\section{References}

Brounen, D., \& Derwall, J. (2010). The impact of terrorist attacks on international stock markets. European Financial Management, 16(4), 585-598. https://doi.org/10.1111/j.1468036X.2009.00502.x

Bysyuk, V. (2010). Impact of 9 / 11 Terrorist Attacks on US and International Tourism Development. MODUL University Vienna, (May), 43.

Elsubbaugh, S., Fildes, R., \& Rose, M. B. (2004). Preparation for crisis management: A proposed model and empirical evidence. Journal of Contingencies and Crisis Management, 12(3), 112-127. https://doi.org/10.1111/j.0966-0879.2004.00441.x

Gupta, A. (2011). Terrorism and its Impact on Financial Performance: A Case of Tourism Industry. 
INTERNATIONAL JOURNAL OF ACADEMIC RESEARCH IN BUSINESS AND SOCIAL SCIENCES

Vol. 10, No. 5, May, 2020, E-ISSN: 2222-6990 @ 2020 HRMARS

International Journal of Financial Management, 1(4), 46-52.

Henderson, J. C., Shufen, C., Huifen, L., \& Xiang, L. L. (2010). Tourism and terrorism: a hotel industry perspective. Journal of Tourism, Hospitality \& Culinary Arts, 2(1), 33-46.

Hobbs, J., Schaupp, L. C., \& Gingrich, J. (2016). Terrorism, militarism, and stock returns. Journal of Financial Crime, 23(1), 70-86. https://doi.org/10.1108/JFC-01-2015-0002

Korstanje, M. E., \& Clayton, A. (2012). Tourism and terrorism: Conflicts and commonalities. Worldwide Hospitality and Tourism Themes, 4(1), 8-25. https://doi.org/10.1108/17554211211198552

Kosová, R., \& Enz, C. A. (2012). 9_11 and the impact on hotel industry in USA.pdf. 53, 308-325.

Mariathasan, J., 2019. Briefing: Sri Lanka after the bombings. [Online] Available at: https://www.ipe.com/briefing-sri-lanka-after-the-bombings/10033006.article [Accessed 2503 2020].

Memdani, L., \& Shenoy, G. (2019). Impact of terrorism on stock markets across the world and stock returns: An event study of Taj attack in India. Journal of Financial Crime, 26(3), 793-807. https://doi.org/10.1108/JFC-09-2018-0093

Paraskevas, A. (2013). Aligning strategy to threat: A baseline anti-terrorism strategy for hotels. International Journal of Contemporary Hospitality Management, 25(1), 140-162. https://doi.org/10.1108/09596111311290264

Shahzad, S. J. H., Stauvermann, P. J., Kumar, R. R., \& Ahmad, T. (2017a). The impact of terrorism on industry returns and systematic risk in Pakistan: A wavelet approach. Accounting Research Journal, 30(4), 413-429. https://doi.org/10.1108/ARJ-09-2015-0114

Shahzad, S. J. H., Stauvermann, P. J., Kumar, R. R., \& Ahmad, T. (2017b). The impact of terrorism on industry returns and systematic risk in Pakistan: A wavelet approach. Accounting Research Journal, 30(4), 413-429. https://doi.org/10.1108/ARJ-09-2015-0114

Vassilikopoulou, A., Siomkos, G., Chatzipanagiotou, K., \& Triantafillidou, A. (2009). Hotels on fire: Investigating consumers' responses and perceptions. International Journal of Contemporary Hospitality Management, 21(7), 791-815. https://doi.org/10.1108/09596110910985296. 